Article

\title{
The Place of Disgust: \\ Disability, Class and Gender in Spaces of Workfare
}

\section{Karen Soldatic $^{1, *}$ and Helen Meekosha ${ }^{2}$}

1 School of Social Sciences, University of New South Wales, Sydney 2052, Australia

2 School of Social Sciences and International Studies, University of New South Wales, Sydney NSW 2052, Australia; E-Mail: h.meekosha@unsw.edu.au

* Author to whom correspondence should be addressed; E-Mail: k.soldatic@ unsw.edu.au; Tel.: +61-2-9385-8942.

Received: 29 November 2011; in revised form: 21 August 2012 / Accepted: 23 August 2012 /

Published: 12 September 2012

\begin{abstract}
This paper explores the role of disgust in mediating disabled women's experience of workfare in the Australian state. As global social policy has been restructured along neoliberal lines in Western nations, the notion of 'workfare' has been widely promulgated. This paper draws on nine case studies from across Australia to explore how this has resulted in disabled women being coerced to participate in a range of workfare programs that are highly bureaucratised, sanitised and moralised. The findings suggest that with the advent of Australian neoliberal welfare reform, some disabled women are increasingly framed in negative affective terms. A primary emotion that appears to govern disabled women forced to participate in Australian neoliberal workfare programs is disgust. The experience of the participants interviewed for this study suggests that the naming of them in negative emotional terms requires disabled women to perform a respectable unruly corporeality to ensure that they gain and maintain access to a range of services and supports, which are vital to their wellbeing.
\end{abstract}

Keywords: disability; gender; class; disgust; respectability; welfare reform

We are scapegoated ... you are sucking the government money, justify it by working. The implication is that we are not working because it's our choice rather than the reality-where we are not working because there is no structure in, there is prejudice out there. It is basically bullying people who can't fight back and taking 
advantage of stereotypes - that we [disabled people ${ }^{1}$ ] are malingering people with minor back problems. Theirs is not an image of a disabled person contributing to society, so it's assumed we are not.

Rachel, Research Participant

So, this is what this welfare reform to me comes across as, is like, you know, people with disabilities are lazy people that just don't want to work.

Marie, Research Participant

It is the way disabilities are seen, they are not on the same level as other people, easier to pull the rug out from under them. You hear it all the time.

Louise, Research Participant

\section{Neoliberalism and Australian Disability Workfare Spaces}

Like many Western liberal democracies, Australia has undertaken extensive welfare restructuring with the rise of neoliberalism as social policy orthodoxy [2]. Neoliberal welfare is often defined as workfare, encompassing a newly defined set of citizenship norms [3]. Embodying notions of exchange in state-citizen relations [4], access to state-funded social security entitlements is tied to participation in a range of state-sponsored labour-market programs which were previously defined by 'need or necessity' $[3,5,6]$. With the onset of neoliberal workfare reforms in Australia, participation in the labour market has become the hegemonic citizenship discourse and is largely reflected in the populist mantra of 'no rights without responsibilities' [7,8]. Thus, Australian workfare trends reflect what Peck and Theodore suggest is the core of the neoliberal argument, that is, that any job is a job worth having, regardless of its conditions, hours or pay [5]. In Australia, the neoliberal restructuring of welfare is articulated in the policy of 'mutual obligation' [9-11], posturing citizen relations as one of absolute exchange [12]; a form of socio-political conscription [13].

Qualifications for disability entitlements have been central to the global restructuring of neoliberal workfare [14-18]. Australia has been both leader and follower in these global trends; indeed, since the late 1990s there has been a plethora of strategies implemented to reduce the number of people accessing the central disability payment - the Disability Support Pension, or DSP [19]. Following the passage of key pieces of legislation in late 2005, the primary criterion used to determine 'disability'the work test-was slashed in half from 30 hours of work per week to just 15 hours of work per week [20]. In Australia, people with an impairment only qualify for a disability pension entitlement if they are defined as disabled under a dual testing regime - the first is an impairment test and the second is a work test based upon potential hours of participation within the open labour market. In September 2011, new legislation was enacted to further these reforms, bringing in stricter impairment criteria, where only the severely disabled are now entitled to disability benefits, shifting the not-so-disabled onto lower unemployment benefits [21]. Many people who had previously qualified for the Disability Support Pension were, and will continue to be, propelled into disability workfare programs as a condition of maintaining access to social entitlements [22]. As Peck suggests, this has been the

1 Throughout this paper we use 'disabled people' and 'disabled women' to refer to processes of disablism that denote the way in which people with impairments are accorded the identity of 'disabled' through structural processes of disablement [1]. 
defining feature of neoliberal reform: individuals now have to earn their citizenship rights and entitlements via the labour market [3].

Integral to neoliberal workfare has been the remapping of civil society labour-market programs $[3,23]$. In Australia these services were initially established through a large civil society network as a direct response to the growing demands of the disability movement in the late 1980s [24], and were symbols of the promise and hope of labour-market inclusion and participation for many within the movement [25]. Formerly suggestive of Harvey's spaces of hope and places of transformative solidarity [26], these services are now subject to highly stipulated state conditions as a requirement of funding.

With the neoliberal turn, state power appears to be extensively mediated via civil society [27]. In Australia this has taken a particular form, where the ideological intent of neoliberal governance has become embedded in a set of defined state-contractual relations, subordinating former civil society values and ethics to neoliberal workfare governance logic, particularly within the disability employment non-government sector [28,29]. New state-contractual relations, embodying New Public Management discourses and the privatisation of welfare, have penetrated the majority of civil society organisations [30,31]. These organisations have all undergone a process of radical reform, with state funding restructured to reflect neoliberal workfare orthodoxies that focus on individual 'behaviour' rather than structural issues of poverty, discrimination and marginalisation [32].

Civil society providers are now contracted by the state to 'case manage' welfare-to-work transitions, and accordingly an associated range of new governing technologies has been trialled, tested and implemented in these spaces [33]. Many of the strategies attempt to disguise structural processes of disability exclusion, discrimination and marginalisation, instead targeting individual behaviour modification, such as the use of individual compacts, to shore up compliance for labourmarket participation [34]. Thornton and Marston reflect that this presents service workers with a set of moral dilemmas, obscuring the historical notions of 'service' upon which these organisations, often charitable or religious, were founded [29].

In Australia, individualised behavioural management strategies for those citizens living on welfareto-work benefits have become more pronounced as state-citizen workfare relations have largely undergone a process which Schram et al. refer to as 'second-order devolution' [23], wherein neoliberal states have shifted sanctioning responsibilities down to the street level. The passage of the Welfare to Work Act (2005) through federal parliament enshrined in law the sanctioning responsibilities of front-line case workers. These workers are now required to observe, monitor and sanction disabled people in workfare programs for a full range of individual misdemeanours and non-compliance [35]. Case-worker discretion has led to a raft of mistakes in which disabled people were cut off from their payments [36]. Recent international research highlights this growing trend across neoliberal workfare states [23,37,38].

All this research signifies the changing relations of place, where front-line case workers are not only experiencing diminishing control over front-line decision-making [39], but are effectively adopting new practices of moral boundary-drawing in their front-line work [40]. Taking our lead from this growing body of work, we explicate the changing relations of disability, gender and class through the narratives of nine disabled women forced to participate in neoliberal workfare programs to maintain access to their social security benefits. The findings from the interviews with these disabled women, and in one instance with the involvement of their case worker, suggest that with the transferral of state sanctioning responsibilities to monitor and survey disabled women's compliance with 
Australian neoliberal welfare-to-work regimes, 'disgust' has become a key technique of governance. In the following section, we explore the theoretical intersections between disability, class and gender with the emergence of neoliberal workfare regimes. Then we provide a brief overview of the disabled women participants of the study before moving to the empirical analysis through drawing upon their stories.

\section{Negotiating Disability, Class and Gender}

In Australia, the political elite have embarked on an intensive campaign of affect, creating a public moral imaginary of the disabled people living on welfare as 'welfare fraudsters' [41]. This is not unique to Australia. In the UK the respectable BBC TV's Panorama documentary series ran an episode on welfare fraud where it was claimed that $£ 22$ billion was stolen or lost through benefit fraud [42]. An Ipsos MORI poll conducted for BBC radio found that while the majority wanted a safety net in terms of a benefits system, 84\% wanted to see stricter testing for incapacity (disability) benefits [43]. The disgusting 'welfare fraudster' has dominated welfare debates with the intensification of neoliberal workfare restructuring over a ten-year period [44].

The prevalence of the disgusting welfare fraudster is not simply about the potentiality of welfare recipients engaging in a range of behavioural practices to subvert state welfare regimes for their individual benefit. The disgusting welfare fraudster, which disabled people are increasingly encountering [45], is tied to the moralisation of their workless status. While this has historically been a distinct feature of being disabled, the neoliberal individual moralisation of worklessness has not just targeted disabled people, but has also targeted the workless working class [40]. This intersectionality of disability and class, as a group of workless people, has not received the attention it has deserved, despite the numerous intersectionalities that appear to exist. As leading critical feminists exploring the subjective experience of the workless working class purport, the moralisation of the female form results in a complex inter-exchange of individual moralisation. We suggest, as identified below, that there are multiple intersecting features between the disabled woman and the working class woman, which become clear when the moralisation of their workless status becomes objectified in public discourse and policy.

As numerous scholars have suggested, disgust has become a prominent theme in neoliberal political debates. In Britain [46], the USA [47] and Australia [44], disgust has promulgated public discussions on people reliant on welfare and the ways in which they have been positioned in public discourse as the abject, the monstrous and the disgusting [18]. Work by prominent feminists, such as Haylett [40,48], Lawler [49] and Skeggs [50], brings to the fore the significant role of the abject, the monstrous and the disgusting in mediating class and gendered relations. The work of these academics is particularly salient in exposing a new moral reimagining of class and gender with the advent of neoliberal regulatory regimes. Within their accounts, the abject, the monstrous and the disgusting play a significant role in regulating working-class women. The working-class female form is reinscribed with new moral meanings, signifying the body as a space of value [50]. This process of inscription is always situated against the respectable middle class, as a means of justifying the growing inequality experienced by the working class, the poor and the disadvantaged, such as disabled people under 
neoliberal regulatory regimes. Haylett suggests that "this discourse solidifies liberal middle-class claims to moral and cultural superiority over others, it is culturally imperialist" ([48], p. 366).

The abject, the monstrous and the disgusting have been dominant themes within critical disability studies. Initially drawing on Mary Douglas's seminal work Purity and Danger, Garland-Thomson, Hughes, LaCom, Schweik and Soldatic have extended Douglas's account to explore the positioning of the disabled body as the space of abnormality, freakery and depravity [12,50-55]. In a similar vein to the work of Haylett, Lawler and Skeggs, these authors all contend that the moral reimagining of the impaired body has been central to the regulation of disability. For example, Schweik, in The Ugly Laws, highlights the continual positioning of disgust in public and legal discourse to support the removal of disabled people from US inner-city streets since the late 1800s [55]. Despite advances in social inclusion through legislation and policy for disabled people, disgust in public discourse remains a means of moral legitimacy to the building of institutions to remove disabled people from the polity [56]. LaCom situates the moral reimagining of the disabled body as abject, monstrous and disgusting in the emergence of modern medicine, denoting the stratification of disabled bodies in accordance with a hierarchy of disgust, from the least to the most disgusting [54]. Combined, these discourses and practices operate as forms of cultural imperialism, where the disabled subject is regulated by what Campbell refers to as able-bodied imperialism [57].

It is apparent that there are numerous overlapping concepts in the theorising of the abject, the monstrous and the disgusting within both feminist and critical disability theory. It is disgust, however, which we feel offers the most promising avenue for exploring the intersections of disability, class and gender with the emergence of neoliberal workfare regimes. Nussbaum argues that disgust "has throughout social history been used as a powerful weapon in social efforts to exclude certain groups and persons" ([58], p. 107) and this appears to be the case under neoliberal workfare regimes. The most salient adverse effect of disgust has been the reimagining of the working class as slothful, lazy and consequently undeserving of public welfare [17,44,46,48].

The moral inscription of bodies with nascent class meanings draws upon three key concepts underpinning the affective framing of disgust, two of which directly intersect with disability theorising on disgust and the impaired body. The first is working-class excess. The inscription of excess to the working class is a process of visualising a morally unworthy subject [50]. As Lawler has articulated, disgust legitimises middle-class sensibilities, where the middle-class body is a space of refined containment [49]. The bodily performance of the respectable middle-class self signifies a highly disciplined repertoire of internal regulation. Regarded as a superior performance of the self, this space of self-regulating regimes gains moral superiority through juxtaposition against a set of bodies that indulge in working-class profanities, such as uncontrolled and excessive drinking. Skeggs suggests that the working-class female form is marked by its conspicuous display of working-class feminine sexuality [50,59]. In Skeggs' accounts, the female working-class form is in contempt of middle-class norms of respectable feminised performance, due to working-class women's loud, expressive voices, and their bodily displays of excessive sexuality. The marking of the working-class body as a site of excess has become more pronounced under neoliberal regulatory regimes.

This theorising on working-class excess is intimately connected to what critical disability theorists refer to as unruly corporealities, where the unruly disabled body represents a direct challenge to a tightly controlled able-bodied performance ([60], p. 61). Writers such as LaCom and Shildrick argue 
that leaky, porous disabled bodies signify the extremes of an unruly corporeality, representing an affront to the normative construction of a tightly controlled, disciplined and contained able-bodied performance [54,61]. The oozing of bodily fluids, uncontrolled bodily spasms, along with unwieldy bodily organs, represents a direct threat to the moral hegemony of a controlled social order. The disabled body's unruly display of one's internal self should be contained deep within the private self, outside of public spaces and places [56]. Unruly disabled bodies signify the possibility of moral contamination with their porous bodily boundaries, and are used as markers to elevate perceptions of the able-bodied self, reproducing social imaginings of the contained, controlled and disciplined able-body [53]. Thus, the unruly disabled corporeality invokes a moral imaginary of uncontained bodies that transgress the able-bodied controlled performance of disciplined internal regulation. The disgusting excessive working-class form shares many properties with the disgusting unruly disabled form. Both sets of bodies are inscribed with normative evaluations that position their bodily performances as abhorrent, revolting and disgusting as compared to the superior social, moral and cultural sensibilities of the middle classes. Disgust is the common thread which ties the excessive working-class body to the unruly disabled body.

The second intersecting concept within both fields of work is that of distancing. As a range of disability theorists have correctly noted, the public abhorrence of the disabled body has been marked by extreme forms of spatial distancing, where the social containment of disabled people within the asylum has been a prominent state regulatory measure. Disgust has played a central role in this process and operates as a cultural, social, political and moral justification for excluding and removing disabled people from public spaces and places [55,56]. The unruly and disgusting disabled body signifies the extremes of human vulnerability [58], which is not solely a socio-biological positioning [62]. This strategy of distancing is also pursued to minimise the risk of contagion that these bodies represent to the moral, social and ethical formations of the self [62]. By establishing 'borders of the self' ([63], p. 26), the able-bodied draws a set of moral normative boundaries to mark out, separate and exclude those bodies that disrupt our internal sense of order. Thus, the development of disability segregation is driven by socio-normative evaluations explicit within disgust.

Processes of distancing have been central to the new moral economy of class. Drawing upon the work of Bourdieu (1984) in their analysis of class, Raisborough and Adams articulate the ways in which distancing has been a marked feature of the respectable middle class - as a mark of class distinction [64,65]. Haylett, Lawler and Skeggs all draw similar conclusions; however, these authors position disgust as central to the middle-class process of distancing, where distancing is a critical feature of maintaining the hegemony of the middle-class subject as morally desirable [48-50]. Ascriptions of value and moral worth are reconstituted through the middle-class practice of distancing itself from working-class profanity and excess. These authors also reveal how disgust and its associated processes of distancing allow a "silent normalisation of such privileged positions" ([49], p. 443).

There are multiple points of interplay between critical disability studies and critical feminist theory. However, a central component of disgust as a mediator of gendered class relations which has not been considered within the disability studies literature is the harnessing of disgust by respectable middle-class women to contain and distance themselves from working-class women. Disgust is pivotal in the formation of respectability [66] and, as Huggins suggests, has long been used by middle-class women "in managing and controlling class relationships" ([67], p. 587). 
Critically, through the work of feminists including Haylett, Lawler and Skeggs, it is possible to identify the ways in which the moral attribution of respectability is integral to neoliberal regulatory practices, wherein the respectable woman establishes 'borders of the self' [63] to distance herself from the disgusting poor, disabled and disadvantaged woman. Skeggs notes the essentialising character of the disgust-respectability continuum in mediating gendered class relations when she argues that poor, disadvantaged working-class women are acutely aware of the ways in which respectable "appearance becomes a signifier of conduct" (original emphasis) ([50], p. 100).

Negotiating the middle-class gendered moral gaze invoked to assess, evaluate and monitor working-class women's performance of respectability is of vital importance to the overall wellbeing of working-class women; hence, these middle-class women have become the primary gatekeepers of the social, cultural and moral capital required for social mobility [59]. The moral assessment of respectability is mediated by disgust and, depending on where on the continuum one falls, requires the ability to hold the respectable gendered middle-class performance in front of the vertical middle-class moral gaze $[44,46,50]$.

The middle-class woman holds extensive power in welfare relations, dominating the professional field [68] and, more significantly, wielding the power to "label them [poor, disabled, working-class women] out of their social and political entitlements" ([69], p. 453). Children are removed from disabled women by social workers who are usually female, involuntary sterilisation of disabled girls is sought by their mothers, and material and other entitlements are often determined by care assessors who are overwhelmingly women [70,71]. While we acknowledge that there are exceptions to this rule-where caseworkers and social workers essentially act as 'allies' with disabled women and may subvert the rules out of commitment to social justice and seek to generate alternative visions for disabled women and girls - we are arguing that the culture of welfare needs a fundamental reformation where the power of assessment is shared between worker and client.

With the increasingly authoritarian structures of 'citizen' compliance embedded in neoliberal workfare regimes [72], our analysis suggests that these dominating political discourses of disgust have permeated boundaries down to the front-line level of the service environment as service workers are required to implement, monitor and control the shifting boundary of the deserving and the undeserving of state support with the intensification of Australian neoliberal workfare. In all, the disabled women participants of this study reveal the ways in which disgust is not just a means to define a set of 'class relations' but, in particular, becomes a unique governing technology to control and monitor the behaviour of disabled women forced into Australian neoliberal workfare programming.

\section{Methodology and the Research Participants}

Both of the researchers have also had extensive involvement with a range of local and national disability rights-based organisations over a long period of time. Given this history, disability rightsbased advocacy groups were initially targeted to support the recruitment of the research participants. This strategy was seen to (a) protect and safeguard the interests of the research participants as these organisations had a relationship with those initially identified and therefore were able to guage their interests and willingness to participate in the project, and (b) ensure that the participants selected had 
some first-hand experience of the changing neoliberal workfare environment. This rich personal experience could be drawn upon to inform the research project.

An initial 30 disabled people were identified as part of a national study conducted by Soldatic; however, most of these were men. While this may be surprising, this reflected the historical and ongoing dominance of disabled men accessing disability employment programs $[73,74]$ and the ways in which disabled women have been, and remain, marginalised from the open labour market due to the stereotyping that emerges with the intersectionality of disability and gender in Australia [75]. To gain access to more disabled women, the disability rights-based advocacy services provided introductions to disability employment services involved in neoliberal workfare programs. In all, nine disabled women were willing to participate in the study. One of the primary reasons for our interest in this particular group is the historical and continuing uneven gender distribution of disability employment services and supports in Australia, and greater insight into disabled women's experience is necessary to critically engage with public policy debates on these issues.

While we are not claiming that findings from a small sample can be generalised, we do believe our analysis will resonate, to a greater or lesser extent, with disabled women across Australia and the industrialised world. Indeed, a previous study by one of the authors, of women going through the rehabilitation and training system in the 1980s, came to very similar conclusions [76].

The nine disabled women who participated in this study came from three states in Australia: Western Australia, New South Wales and Victoria. All the participants were located within the main cities of these states (Perth, Sydney and Melbourne); however, of those living in Sydney and Melbourne, most resided in the outer suburbs. The disabled women from Perth were mostly within a 10-kilometre radius of the city.

The women had a range of impairment types, though the realm of sensory impairment was the most dominant, with seven participants having a vision impairment and one with hearing impairment as a secondary disability. All except one of the participants, Rachel, had experienced either no or short-term intermittent employment over the 2-5 years prior to the interviews. The interviews were conducted in a range of settings, either at the participants' homes, at the disability rights-based advocacy organisations or, in the case of Theresa - a young woman with a dual sensory and neurological impairment - at the disability workfare organisation. Before the interviews commenced, the lead researcher, Soldatic, discussed the purpose of the project and asked if participants consented to (a) participating in the study and (b) being recorded. Transcripts were then made anonymous to protect their identities.

\section{The Place of Disgust: Disability, Class and Gender}

The process of creating a negative identity for disabled people began with the announcement of disability workfare restructuring by the political elite. The nine working-class disabled women who participated in this study were aware of this political strategy to delegitimise their claims for disability entitlements at the macro scale. More specifically, these women highlighted the ways in which maintaining a disabled identity as a woman living on welfare was constantly questioned within disabled places of workfare. In attempting to gain access to the necessary supports to move from welfare to work, these women were constantly required to reiterate the validity of their disabled identity. 
As Miller notes, one of the key features of disgust is that "[W]e end up punishing the stigmatized, who may have no justifiable cause for feeling guilt for their stigma" ([66], p. 202). Melissa, a woman in her early twenties from Perth, articulates this process when she highlights the repetitive barrage of questions that she has had to endure when applying for disability employment support following the advent of workfare: "[T]his is the third interview ... at which I've answered questions about the type of work I'm seeking and how my vision impairment and other factors will affect my employment."

The constant questioning of working-class disabled women and their claims for disability entitlements is about both "establish[ing] or confirm[ing] ... social and moral worth" ([66], p. 217). Within these spaces, disgust operates as a 'policing exercise' ([77], p. 90) employed to detect and exclude fraudulent bodies. Julia, from Perth, identifies the way in which disgust has become central to policing disabled women with the advent of neoliberal workfare when she states that the disability workfare reforms are:

“... geared to shunting us off to employment agencies and a lot of referrals, paperwork, applications. I felt it was more a run-around, going to them and I felt like I had to train them, whereas they were getting paid to help us. We were in effect doing twice the running around."

Here, disgust works to contain working-class disabled women within the nascent spaces of disability workfare. Once contained inside these spaces, disabled women can then be actively policed by case workers who have been charged with new sanctioning powers. These disabled women have to repeatedly legitimise their claims to a disabled identity worthy of state support, in addition to working hard to ensure that the middle-class case worker understands what their bodies are worth as willing but, contradictorily, able workers.

The disabled women who participated in this study reflected on the ways in which their bodies had been inscribed with the new moral evaluative framework, which had the power to deny them access to the resources they needed. As Susie, a working-class disabled woman living on welfare in Sydney, suggests, you are required to assert your legitimacy for a disability claim while simultaneously ensuring that you are not too unruly, as excess unruliness may be detrimental to securing access to vital resources. She states that, "it is like an extra step to demonstrate that you are worth it. If you do speak up it is seen as, 'She has got a chip on her shoulder'."

The power of disgust also resides in its ability to compel those with a deeply stigmatised identity, such as the women of this study, to "internalise the social judgements made of their stigmatisation as shame, self-loathing, self-disgust, self-contempt and self-hatred" ([65], p. 202). The repetitive questioning of one's legitimacy in terms of disability status and the ongoing surveillance that the disabled women in this study endure within disabled workfare spaces has left them with internalised feelings of self-disgust. Shumie describes this process when narrating her most recent experience of being 'rated' and 'classified' by her case worker. Shumie identifies the internal distrust that emerges when one is continuously faced with a system that defines you with moral disgust. Similarly to Susie, Shumie articulates the ways in which she has begun to self-regulate her behaviour to protect herself from the middle-class moral gaze of disgust: "Then, what happens is that you sort of sit there in the office and they basically are meant to rate you from one to five. You sort of sit there going, 'I wonder how much more to divulge'." 
Rachel, a woman in her mid-thirties with cerebral palsy, has been involved in a number of workfare programs, but has refused to register for any more, following the advent of sanctioning powers awarded to case workers within disability workfare spaces. In Rachel's experience, disgust has been the signifier of her most recent and final relationship with her case worker. Rather than taking on the identity of a disgusting welfare fraudster, Rachel mounted a direct challenge, which resulted in a hail of bullying, harassment and surveillance, even within the home:

"I was at the point she had me so terrified, haranguing and bullying me, I took the phone off the hook and all but hid under the bed. She set up an interview for me and I wasn't going to go because I didn't want to. She turned up at my door with another staff member from the agency who I had never met before; these women sat in my living room and proceeded to lecture me for 45 minutes on the realities of looking for work when you have a disability. Two able-bodied women, I might add, lecturing me about not expecting all places to be accessible.”

Thus, Rachel has resisted the moral stigmatisation that has emerged with her workless status as a disabled woman living on welfare entitlements, despite the propensity of workfare discourses and practices to moralise such behaviour and individualise resistance to workfare as belonging to the abject welfare workless fraudster and therefore, morally undeserving of state support, rights and entitlements [13].

Haylett, in her work with Afro-American working-class women forced into workfare programming in the USA, clearly identifies the necessity of claiming respectability for oneself within neoliberal spaces, as a means to shed oneself of the moral attributes inscribed as disgust [40]. Shedding gendered class markers that signify disgust through the performance of respectability is critical to permeating class boundaries as a socially mobile subject. Skeggs [59] suggests that working-class women have found themselves profoundly conflicted in attempting to gain the moral respectability awarded to white middle-class women in their interactions within the public sphere, while simultaneously resisting those same notions of respectability internally. Working-class disabled women are not only expected to take on gendered forms of 'respectable' performance, but are actually coached by disability labour-market service workers in precisely how to do so [76]. ${ }^{2}$ Theresa, a working-class disabled woman, lives with her parents, one of whom is deaf, in an outer Melbourne suburb. In the dialogue below, Theresa and her disability case manager discuss with the researcher Theresa's work to overcome her daily practices of impairment, which the case worker marks out as culturally undesirable, drawing on moral discourses of disgust:

IOE2: So, Theresa has really come a very long way. I guess we have done a lot of work together, haven't we? There has been a bit of counselling involved. Would you agree with that?

2 This study of the Commonwealth Rehabilitation Services and its services for women in the mid-1980s revealed that while the head of the organisation was committed to improving access for women clients, a significant number of senior staff identified moves towards equity for women as discrimination against men. In 1984/5 women made up only $30 \%$ of clients. In the same year the outcomes for women post-rehabilitation and training showed that women were five times more likely to have an occupation status as 'home duties' than men. The research uncovered pervasive thinking that disabled women did not seriously want or need to work. In one rehabilitation institution the only priority for women was seen as a self-care program involving contact with major fashion and make-up enterprises ([76], p. 140). 
Theresa: Yes.

IOE2: Theresa used to get really over-excited, didn't you? Like, you would come in and you would be talking at 100 miles an hour, and real loud.

Theresa: Really loud.

IOE2: We discussed that, and you have worked so well on that. You know now that there is no need to nearly send me deaf. There is no need for it.

Theresa: You see, I have got a deaf father, and an almost deaf mother, and a deaf grandmother, so you kind of got these-

IOE2: I don't want to be the next one in line.

Theresa: We talked about that.

IOE2: So, Theresa has really taken that on board. We have just got this really good rapport going where I can be completely honest with Theresa, and Theresa will take that on board, and that is fantastic. All of these skills are to help you at work, you know.

Theresa is achieving a milestone on the respectability ladder. Some of her qualities, which are potentially associated with her neurological impairment, are framed as 'over-excited', signifying an unruly corporeality. Campbell refers to this ontological construction of ableism as the misrecognition of differing corporealities [57]. However, Campbell's analysis of ableism, which includes gender and disability, does not address class. Theresa, as a subject, is inscribed not only by the cultural reproduction of ableism, but also by those of class and gender, as a working-class woman living on state welfare. The female form, as Thomas argues, is a feminised space of disablement, class and gender [78] and, as Clear and Gleeson have suggested, the cultural reproduction of ableism emerges from the materiality of disability social relations [79].

Moreover, Theresa's loudness is associated with disgust, as it symbolises the drawing of attention to her class-based excess. Skeggs argues that this process of embodiment symbolises working-class women's disruption of respectable middle-class gendered embodiment [50]. Theresa's disabled working-class femininity, and its reproduction within the household, is stripped of its legitimacy as a form of social being. In the dialogue above, it is interpreted by the disability social worker as an intrusion into public spaces of neoliberal workfare meta-governance. We see the role of disgust throughout this dialogue and the threat of contagion as it permeates bodily borders through the case worker's statement that "I don't want to be the next one in line", referring to the possibility of contamination by Theresa's daily lived practices of impairment and working-class embodiment, resulting in a process of what Tyler refers to as being abject by how our embodiment is defined in relation to the middle-class respectability [80].

The service worker's middle-class feminine respectability is not only legitimised through this process, but also extends itself to colonise poor disabled women's bodies-as a form of cultural imperialism [50,57]. Disability workfare spaces have become the new factories for producing and reproducing the 'normal'. It also expands Skeggs' argument on middle-class feminine respectability, which states that the lived existence of working-class female forms is subject to specific practices of cultural reproduction [59]. For disabled working-class women, a tightly controlled performance of 
able-bodied middle-class respectable femininity becomes a necessary part of their daily practices in order to receive the vital services and resources they need to gain access to the labour market.

Finally, practices of regulating classed and gendered respectability also involved enforcing middleclass moral codes of mothering. While the political elite perpetuated the moral imagery of a morally fraudulent welfare subject, requiring behavioural intervention, disability workfare spaces engaged in 'social practices of morality' [81]. The bodies of working-class disabled women that fell within the reproductive sphere were tightly regulated to ensure they complied with white middle-class moral codes of mothering, as Emma, a young single mother with a psychiatric illness living in Victoria, discovered:

Emma: She got the authorities onto me because she thought that I wasn't looking after my son well and she thought that I didn't know how to spend my money because I used to spend my money like it grows on trees.

Researcher: Is that what she said to you?

Emma: Yeah, because I had problems paying childcare.

Researcher: Did you feel that was true?

Emma: No.

Emma receives a NewStart Allowance rather than a Disability Support Pension, and therefore receives a lower income payment and associated entitlements, despite having a diagnosis of mental illness. As a result, the level of material hardship she experiences is much greater than that of a disabled woman with children on a DSP. Emma is one of the liminal people caught 'in between', resulting from the state's adoption of a number of practices to diminish the number of disabled people accessing disability entitlements. Rather than recognising the structural material deprivation of Emma's position, the case worker misrepresents Emma's position as individualised pathology, and as an inherent flaw in her moral character. Emma's status as a working-class disabled woman, undeserving of disability entitlements, is further pathologised by her status as a single mother.

Skeggs suggests that such a process also enables middle-class women to become upwardly mobile as they 'fix' poor working-class women for their own advantage [50]. Marking Emma as unruly and non-compliant reproduces the case worker's respectability as the benevolent middle-class woman. The material deprivation which affects Emma's ability to pay for childcare is marked out as excess by Emma's recounting of the case worker's interpretation of her material reality as "spend[ing] ... money like it grows on trees". Unruly poverty, experienced by most disabled people surviving on workfare payments, can thus be seen to entail a process of moralising the feminine disabled working-class subject against the normate respectable middle-class woman. ${ }^{3}$ This juxtaposition signifies the way disgust functions to "maintain distance whilst in proximity" (original emphasis) ([50], p. 102) between the case worker and Emma, encapsulating the reproduction of power within workfare spaces of meta-governance.

3 Our meaning of 'unruly poverty' as distinct from 'poverty' is to capture the ways in which disability results in higher levels of poverty, as compared to the 'able-bodied', due to the additional costs incurred to sustain even an absolute basic level of wellbeing (rather than relative level of wellbeing), such as additional transport costs, pharmaceutical goods and medical products, and specialised dietary requirements, from living in an exclusionary society [82]. 


\section{Conclusions}

By combining the critical disabilities studies literature on disgust with that of critical feminist theory, we have identified the varying forms of neoliberal workfare regulatory practices that have emerged in Australian disability workfare programming. Disabled women interviewed as part of this study were able to articulate the ways in which they had been reimagined in public discourse and representation as the disgusting 'welfare fraudster' by the political elite at the national level. More significantly, through their narratives, we have illuminated the way in which disgust has traversed the boundaries of place. The respectable middle-class case worker drew upon disgust to manage the welfare-to-work transitions of some working-class disabled women, which, in some instances, directly denied them access to the vital resources they needed, not only for social mobility, but in order to sustain an adequate level of material and emotional wellbeing.

With the emergence of neoliberal workfare as social policy hegemony, the nation-state's political reimagining of the disabled person on welfare as the disgusting 'welfare fraudster' has radically reconfigured disability relations within environments that were initially designed to support disabled people's inclusion, participation and representation. Consequently, a new set of socio-relations has emerged to govern disabled people forced to move through these spaces. The preceding analysis has ascertained that processes of embodiment are shaped, framed and regulated by the affective spatial dynamics of power. Disgust has been a dominating moral, social and cultural discourse and practice in shaping these processes of embodiment. All nine disabled women could clearly articulate the growing presence of disgust, along with the diverse processes of negotiation required to maintain their distance from its increasing power. Simultaneously, the respectable case worker drew upon disgust to "maintain distance whilst in proximity" [50]. Thus, disgust has always been, and recently has become blatantly apparent, a key technique of governance within disability workfare spaces and the gendered relations that these entail.

As suggested in the theoretical discussion earlier in this paper, the disabled identity is not only gendered but also bears markers of class, particularly for those disabled women forced to participate in state-sponsored neoliberal workfare spaces due to their working-class location. The neoliberal reproduction of the benevolent respectable woman draws upon a set of moral boundaries, sorting, dividing and classifying the worthy from the unworthy working-class subject [40]. While we acknowledge that this is not always the case, often the respectable case worker's moral imagining and marking of the disabled women living on welfare benefits with either disgust or respectability mediates access to the vital social, moral and cultural capital necessary to become socially mobile. In many instances, the disabled women participating in this study had to carry out a 'tightly controlled tightrope performance', balancing the act of disabled unruliness with middle-class respectability in order to maintain access to these vital resources.

These disabled women had to move up the respectability ladder in the eyes of the middle-class case worker, from the disgusting to the respectable in an attempt to moderate or overcome her disability. The disgust-respectability continuum was central to this movement, and reveals that the class positioning of disabled women shapes their experience of workfare within these spaces. As authors, our hope is that this study will provide the impetus for greater elaboration on the disabled identity to ensure that the full gamut of complex and daily lived disabled identities is captured and represented. 
Further, we hope that this paper encourages the critical examination of the contradiction of disabled people's right to work as central to citizenship claims [83] and the ways in which this demand has actively undermined disabled people's just claims for welfare social provisioning as an entitlement of citizenship (see $[19,84]$ ).

Finally, there is a conspicuous absence of the notion of respectability within disability feminist accounts. Though disabled women are constantly moving through a diverse range of helping spaces and places $[15,38,85]$, there is limited academic understanding of the ways in which respectability mediates gendered class (dis)abled relations. We would suggest that this is likely due to the lack of interest in the class stratification of disability within the field itself. The general tendency is to situate disabled people as a homogeneous class category, and while disabled feminist analysis has deepened the analytic lens of disability gendered relations, it has yet to explore the realm of respectability in mediating able-bodied/disabled gendered class relations.

As this paper reveals, performing respectability is of extreme material importance to working-class disabled women living on workfare, and is thus conceptually critical to elaborating the shared experience of class for disabled women within these spaces. From an academic perspective, therefore, we advocate not only for further research which elucidates gendered disablement, but also for research which seeks to explain the stratification of disability along class lines. This task is vital to identify possible strategies of resistance within these spaces, and more importantly, to advance working-class disabled women's collective struggle for respect, recognition and redistribution.

\section{References}

1. Thomas, C. Sociologies of Disability and Illness; Palgrave Macmillan: Basingstoke, UK, 2007.

2. Mendes, P. Australia's Welfare Wars Revisited: The Players, the Politics and the Ideologies, 2nd ed.; UNSW Press: Sydney, Australia, 2008.

3. Peck, J. Workfare States; The Guilford Press: New York, NY, USA, 2001.

4. Moss, J. 'Mutual obligation' and 'new deal': Illegitimate and unjustified? Ethical Theory Moral Pract. 2006, 9, 87-104.

5. Peck, J.; Theodore, N. 'Work first': Workfare and the regulation of contingent labour markets. Camb. J. Econ. 2000, 24, 119-138.

6. Carney, T. Neoliberal welfare reform and 'rights' compliance under Australian social security law. Aust. J. Hum. Right 2006, 12, 223-253.

7. Bessant, J.; Watts, R.; Dalton, T.; Smyth, P. Talking Policy: How Social Policy is Made; Allen \& Unwin: Sydney, Australia, 2006.

8. Fiske, L.; Briskman, L. Rights and responsibilities: Reclaiming human rights in political discourse. Just Policy J. Aust. Soc. Policy 2007, 1, 50-54.

9. Goodin, R.E. Structures of mutual obligation. J. Soc. Pol. 2002, 31, 579-596.

10. Harris, P. From relief to mutual obligation: Welfare rationalities and unemployment in 20thcentury Australia. J. Sociol. 2001, 37, 5-26.

11. Yeatman, A. Mutual obligation: What kind of contract is this? In Reforming the Australian Welfare State; Saunders, P., Ed; Australian Institute of Family Studies: Melbourne, Australia, 2000; pp. 156-176. 
12. Soldatic, K. Disability and the Australian Neoliberal Workfare State; unpublished PhD thesis; University of Western Australia: Perth, Australia, 2010.

13. Bessant, J. Civil conscription or reciprocal obligation: The ethics of 'work-for-the-dole'. Aust. J. Soc. Issues 2000, 35, 15-33.

14. Barnes, C.; Mercer, G. Disability, work, and welfare: Challenging the social exclusion of disabled people. Work Employ. Soc. 2005, 19, 527-545.

15. Chouinard, V.; Crooks, V.A. 'Because they have all the power and I have none': State restructuring of income and employment supports and disabled women's lives in Ontario, Canada. Disabil. Soc. 2005, 20, 19-32.

16. Hyde, M. From welfare to work? Social policy for disabled people of working age in the United Kingdom in the 1990s. Disabil. Soc. 2000, 15, 327-341.

17. Grover, C.; Piggott, L. Disgusting! Understanding Financial Support for Disabled People in the UK. Presented at the Disability Studies 5th Bi-annual Conference, Lancaster University, Lancaster, UK, September 2010.

18. Russell, M. Beyond Ramps: Disability at the End of the Social Contract: A warning from an Uppity Crip; Common Courage Press: Monroe, ME, USA, 1998.

19. Galvin, R. Can welfare reform make disability disappear? Aust. J. Soc. Issues 2004, 39, 343-353.

20. Meekosha, H. A feminist/gendered critique of the intersections of race and disability: The Australian experience. Presented at University of British Columbia, Vancouver, Canada, 23 June 2005.

21. People with Disability Australia. August 2011, 71, p. 10. Available online: http://pwd.org.au/ documents/pubs/EB71.html (accessed on 11 September 2011)

22. National Welfare Rights Network. Fact Sheet: Changes to Disability Support Pension. Available online: http://www.welfarerights.org.au/default.aspx (accessed on 12 October 2011).

23. Schram, S.F.; Fording, R.C.; Soss, J. Neo-liberal poverty governance: Race, place and the punitive turn in US welfare policy. Camb. J. Reg. Econ. Soc. 2008, 1, 17-36.

24. Department of Community Services. New Directions: Report of the Handicapped Programs Review; Australian Government Publishing Service: Canberra, Australia, 1985.

25. Clear, M. Promises, Promises: Disability and Terms of Inclusion; Federation Press: Sydney, Australia, 2000.

26. Harvey, D. Spaces of Hope; University of California Press: Berkeley, CA, USA, 2000.

27. Maddison, S.; Martin, G. Introduction to 'Surviving neoliberalism: The persistence of Australian social movements'. Soc. Mov. Stud. 2010, 9, 101-120.

28. Ramia, G. The 'new contractualism', social protection and the Yeatman thesis. J. Sociol. 2002, 38, 49-68.

29. Thornton, S.; Marston, G. Who to serve? The ethical dilemma of employment consultants in nonprofit disability employment network organisations. Aust. J. Soc. Issues 2009, 44, 73-89.

30. McDonald, C.; Chenoweth, L. (Re) shaping social work: An Australian case study. Br. J. Soc. Work 2009, 39, 144-160.

31. Ramia, G.; Carney, T. New public management, the job network and non-profit strategy. Aust. J. Lab. Econ. 2003, 6, 253-275. 
32. Soldatic, K.; Meekosha, H. Disability and neoliberal state formations. In Routledge Handbook of Disability Studies; Watson, N., Thomas, C., Roulstone, A., Eds.; Routledge: London, UK, 2012.

33. McDonald, C.; Marston, G.; Buckley, A. Risk technology in Australia: The role of the job seeker classification instrument in employment services. Crit. Soc. Pol. 2003, 23, 498-525.

34. Martin, S. Welfare Reform, the Underclass Thesis and the Process of Legitimising Social Divisions. In Proceedings of the Australasian Political Studies Association Annual Conference, Monash University, Melbourne, Australia, September 2007.

35. Meekosha, H.; Dowse, L. Integrating critical disability studies into social work education and practice: An Australian perspective. Practice 2007, 19, 169-183.

36. McMillan, J. Application of Penalties Under Welfare to Work, Report No. 16; Commonwealth Ombudsman: Canberra, Australia, 2007.

37. Fording, R.C.; Soss, J.; Schram, S.F. Devolution, discretion, and the effect of local political values on TANF sanctioning. Soc. Ser. Rev. 2007, 81, 285-316.

38. Magaña, S.; Parish, S.L.; Cassiman, S.A. Policy lessons from low-income mothers with disabilities. J. Women Polit. Pol. 2008, 29, 181-206.

39. Soldatic, K.; Meekosha, H. Moving the boundaries of feminist social work education with disabled people in the neoliberal era. Soc. Work Edu. 2012, 31, in press.

40. Haylett, C. Remaking labour imaginaries: Social reproduction and the internationalising project of welfare reform. Polit. Geogr. 2003, 22, 765-788.

41. Vanstone, A. Queensland raid catches welfare fraudster; Australian Government, Canberra, Australia, 2002. Available online: www.formerministers.fahcsia.gov.au/amandavanstone/ mediareleases/2002/Pages/Media_R_05022002.aspx (accessed on 22 November 2011).

42. BBC. Britain on the Fiddle; Panorama, UK, 2011. Available online: www.bbc.co.uk/programmes/b016lty2 (accessed on 22 November 2011).

43. Ipsos MORI. Vast majority support benefits system - but want the system to be stricter; BBC 2 Radio: UK, 27 October 2011. Available online: www.ipsos-mori.com/researchpublications/ researcharchive/2876/Future-State-of-Welfare.aspx (accessed on 22 November 2011).

44. Soldatic, K.; Pini, B. The three Ds of welfare reform: Disability, disgust and deservingness. Aust. J. Hum. Right 2009, 15, 77-96.

45. Walker 2012 Benefit cuts are fuelling abuse of disabled people, Guardian 5 February 2012. Available online: https://sinprd0202.outlook.com/owa/?ae=Item\&a=Open\&t=IPM.Note\&id=RgA AAAB3rz7XSySSRryxV0oFCRtcBwCEOZ2DyG60T7mw2W6cgQHZAAAmyiAXAAADm4fP\% 2bmkFQ6dToaYD4HuZAAAOvF9bAAAA\&pspid=_1329480522245_657785290 (accessed on 7 February 2012).

46. Tyler, I. Chav mum chav scum. Fem. Media Stud. 2008, 8, 17-34.

47. Hancock, A.M. The Politics of Disgust: The Public Identity of the Welfare Queen; NYU Press: New York, NY, USA, 2004.

48. Haylett, C. Illegitimate subjects?: Abject whites, neoliberal modernisation, and middle-class multiculturalism. EPD: Soc. Space 2001, 19, 351-370.

49. Lawler, S. Disgusted subjects: The making of middle-class identities. Sociol. Rev. 2005, 53, 429-446.

50. Skeggs, B. Class, Self, Culture; Routledge: London, UK, 2004. 
51. Douglas, M. Purity and Danger: An Analysis of Concepts of Pollution and Taboo; Routledge: New York, NY, USA, 1966.

52. Garland-Thomson, R. Staring: How We Look; Oxford University Press: New York, NY, USA, 2009.

53. Hughes, B. Wounded/monstrous/abject: A critique of the disabled body in the sociological imaginary. Disabil. Soc. 2009, 24, 399-410.

54. LaCom, C. Filthy bodies, porous boundaries: The politics of shit in disability studies. Disabil. Stud. Q. 2007, 27, 1-14.

55. Schweik, S.M. The Ugly Laws: Disability in Public; NYU Press: New York, NY, USA, 2009.

56. Soldatic, K. Disgust and the Moral Economy of Disability. Presented at Australian Sociological Association/Sociological Association of Aotearoa conference, Auckland, New Zealand, December 2007.

57. Campbell, F.K. Contours of Ableism: Territories, Objects, Disability and Desire; Palgrave Macmillan: Basingstoke, UK, 2009.

58. Nussbaum, M.C. Hiding from Humanity: Disgust, Shame, and the Law; Princeton University Press: Princeton, NJ, USA, 2004.

59. Skeggs, B. Formations of Class and Gender: Becoming Respectable; Sage Publications: London, UK, 1997.

60. Wendell, S. The Rejected Body: Feminist Philosophical Reflections on Disability; Routledge: New York, NY, USA, 1996.

61. Shildrick, M. Dangerous Discourses of Disability, Subjectivity and Sexuality; Palgrave Macmillan: New York, NY, USA, 2009.

62. Miller, S.B. Disgust: The Gatekeeper Emotion; The Analytic Press: Hillsdale, NJ, USA, 2004.

63. Rozin, P.; Fallon, A.E. A perspective on disgust. Psychol. Rev. 1987, 94, 23-41.

64. Bourdieu, P. Distinction; Routledge: London, UK, 1984.

65. Raisborough, J.; Adams, M. Mockery and morality in popular cultural representations of the white, working class. Socio. Res. Online 2008, 13, 2:1-2:13.

66. Miller, W.I. The Anatomy of Disgust; Harvard University Press: Cambridge, MA, USA, 1998.

67. Huggins, M. More sinful pleasures? Leisure, respectability and the male middle classes in Victorian England. J. Soc. Hist. 2000, 33, 585-600.

68. Huppatz, K. Respectability and the paid caring occupations: An empirical investigation of normality, morality, impression management, esteem in nursing and social work. Health Sociol. Rev. J. Health Sec. Aust. Sociol. Assoc. 2010, 19, 73-85.

69. Reiff, R. The control of knowledge: The power of the helping professions. J. Appl. Behav. Sci. 1974, 10, 451-461.

70. Dowse, L.; Frohmader, C.; Meekosha, H. Intersectionality: Disabled women. In Women and the Law in Australia; Eastreal, P., Ed.; LexisNexis: Sydney, Australia, 2010; pp. 249-268.

71. Malacrida, C. Gendered ironies in home care: Surveillance, gender struggles and infantilisation. Int. J. Incl. Educ. 2009, 13, 741-752.

72. Tickell, A.; Peck, J. Making global rules: Globalisation or neoliberalisation? In Remaking the Global Economy: Economic-Geographical Perspectives; Peck, J., Wai-Chung Yeung, H., Eds.; Sage: London, UK, 2003; pp. 163-181. 
73. Department of Family and Community Services. Australian Government Disability Services Census: 2002; Australian Government: Canberra, Australia, 2004.

74. Department of Families, Housing, Community and Indigenous Affairs. Australian Government Disability Services Census 2008; Australian Government: Canberra, Australia, 2010.

75. Salthouse, S. Jumping Through Hoops: Welfare and Industrial Relations Reform Implications for Women with Disabilities. Presented at What Women Want Workshop, Women with Disabilities Australia, Canberra, Australia, July 2005.

76. Meekosha, H.; Department of Community Services and Health. Breaking In and Breaking Out: A Study of Women, Disability and Rehabilitation in Australia; Department of Community Services and Health: Canberra, Australia, 1987.

77. Soper, K. What is Nature? Culture, Politics and the Non-human; Wiley-Blackwell: Oxford, UK, 1995.

78. Thomas, C. Female Forms: Experiencing and Understanding Disability; Open University Press: Buckingham, UK, 1999.

79. Clear, M.; Gleeson, B. Disability and materialist embodiment. J. Aust. Polit. Econ. 2002, 49, 34-55.

80. Tyler, I. Against abjection. Fem. Theor. 2009, 10, 77-98.

81. Sayer, R.A. The Moral Significance of Class; Cambridge University Press: Cambridge, UK, 2005.

82. Burchardt, T.; Zaidi, A. Disabled children, poverty and extra costs. In Why Money Matters: Family Income, Poverty and Children's Lives; Strelitz, J., Lister, R., Eds.; Save the Children, London, UK, 2008; pp. 26-33.

83. Barnes, C.; Mercer, G. Exploring Disability; Polity Press: Cambridge, UK, 2010.

84. Soldatic, K.; Chapman, A. Surviving the assault? The Australian disability movement and the neoliberal workfare state. Soc. Mov. Stud. 2010, 9, 139-154.

85. Crooks, V.A. Income assistance (the ODSP) and disabled women in Ontario, Canada: Limited program information, restrictive incomes and the impacts upon socio-spatial life. Disabil. Stud. $Q$. 2004, 24, 1-9.

(C) 2012 by the authors; licensee MDPI, Basel, Switzerland. This article is an open access article distributed under the terms and conditions of the Creative Commons Attribution license (http://creativecommons.org/licenses/by/3.0/). 